\title{
Killers on the loose
}

\section{Nature Vol.434(123)/10 March 2005}

開発途上国全体に深刻な問題が存在する。市場に偽造薬品が出まわり、本物との区別ができないのだ。 援助国、当事国の政府、製薬業界による対応が求められている。

東南アジアを訪れたことがあるならば、ニセモノ商品であふ れた店が立ち並ぶ街角に行ったことはないだろうか。まさ にそこでロレックス時計のニセモノや海賊版 DVD を買った 人もいるかもしれない。アジアではよくあることだが、これ は確かに違法行為である。それでも多くの観光客は、ニセ モノ商人をロビンフッドのような義賊ととらえている。つま り、裕福な欧米企業から利益をかすめとり、地元の現金経 済を潤す存在だと考えられているのだ。

しかし、アジアのニセモノ文化にはもう1つの側面がある。 それは普通、観光客の目に触れることはない。ラベルに書か れた有効成分の量が足りなかったり、全く含まれていなかっ たりする偽造薬品が薬局にあふれているのだ。このインチキ 薬は、ほとんどが中国かインド製で、アフリカやその他の開 発途上国にも輸出されている。この商売には善意のかけら も見られない。偽造薬品は慢性疾患を引き起こし、孤児や 未亡人を生みだす。関係している連中は冷酷非情で、人間 の命がどうなろうとあまり気にしていない。そしてこの商売 は、こうした現状を見て見妨りする腐敗した役人がいる ところで繁盛する。

だが幸いなことに、開発途上国での偽造医薬品の問題に ついての認識が高まってきている。一部の最貧国で医療水 準の向上に努力している研究者や医師の助力によって、こ の話に注意が呼びかけられている (Nature 2005 年 3 月 10 日号 p.132 参照)。最近では、この問題点に取り組むた めの複数のプログラムが創設された。例えば、国際商業会 議所は 2003 年に偽造医薬品イニシアチブを設立し、偽造 薬品に関する情報収集や情報交換を行っている。

多国籍製薬会社も、この問題との関わりを持ち始めてい る。そのうちの数社が集まって医薬品セキュリテイ協会が設 立された。ここでは刑事訴追を行う可能性も念頭において、 偽造医薬品の製造に関する情報を集めている。製薬会社が このような動きに出た背景には、先進国の裕福な消費者を ターゲットにしてインターネット上で取引される、偽造医薬 品の売買の増加がある。これは会社の売上に影響し、大手
製薬会社の経営を左右するような問題となっている。

それでも製薬会社各社は、商売上の秘密情報を他社に開 示することには慎重だ。この問題が報道されることによっ て自社製品に対する消費者の信頼が損なわれることを恐れ、 社内デー夕をなかなか公表しょうとはしない。また、偽造 薬品による人的被害の最も涾刻な開発途上国での偽造薬品 問題に対する取組みにも身が入っていない。これに対して、 偽造薬品の脅威と戦う団体は、より積極的な展開をしたい のだがそのための資源が足りないと語る。各国政府と製薬 会社は必要とされる資源を提供し、偽造薬品の業者を野放 しにしている国々に対する圧力を強め、悪徳業者に法の裁 きを受けさせるべきである。

ある欧米系政府機関の職員は、カンボジア国内での偽造 薬品問題や盛んな偽造薬品取引の背景となっている腐敗し た環境に注目したために同国政府高官の怒りを買い、上司 にこの問題から手を引くよう言われたという。援助プロジェ クトは受入国側の理解がなければ実施できないので、この 上司はプロジェクト全体が危うくなってしまうことを心配し たのだと思われる。

しかし、このような姿勢は間違っており、許されるもの ではない。偽造医薬品商売の背後には、厳しい取り締まり と重い刑罰のために商売替えをした、かつての麻薬密輸業 者が多く介在している。このような邪悪な組織的犯罪者は、 事実上の殺人を犯しているにもかかわらず、処罰を免れて いる。このような状況を許すべきではない。

解決策は簡単には見つからない。偽造薬品の問題が最も 深刻な国々では、誰が問題を解決しょうとする側の人間で、 誰が問題を起こしている側の人間なのかを区別できないこ ともある。だからといって何もしないでよいわけではない。 哲学者エドマンド・バークが言ったように、「悪を栄えさせ

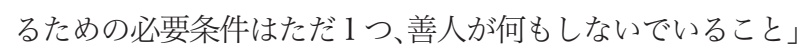
なのである。 